\title{
ТИБОР ФРАНК
}

\section{СЛЕПОЙ СВИДЕТЕЛЬ \\ АМЕРИКАНСКИЙ ПОСОЛ ДЖОЗЕФ Э. ДЭВИС В МОСКВЕ, 1936-1938}

\section{THE BLIND EYEWITNESS \\ U.S. AMBASSADOR JOSEPH EDWARD DAVIES IN MOSCOW, 1936-1938}

Joseph Edward Davies (1876-1956) was U.S. ambassador to Moscow between 1936 and 1938. Davies was a lawyer who joined the Democrats and contributed to the success of the presidential election of Woodrow Wilson whom he supported in various capacities during his two terms 1912-1920. He was a close companion of Wilson before he became an international lawyer between the U.S. and Mexico, Peru, The Netherlands, Greece and the Dominican Republic. He was mainly involved in anti-trust cases representing Seagrams, National Dairy, Copley Publishing, Anglo-Swiss, Nestlé and Fox Films. Joseph E. Davies supported the presidency of Franklin Delano Roosevelt who sent him in 1936 with his newly wed wife, the former Mrs. Post, as a U.S. ambassador to Moscow. Amb. Davies was led astray by his Soviet hosts, probably through the valuable art gifts he received for his personal art collection. He became as it were blindfolded while studying the Soviet Union and, especially, during the showtrials when he was called upon to watch closely and serve as a witness. The ambassador seemed to believe all the horrible crimes the victims of these trials accused of and showed no doubts whatsoever as to the trials. He sent his reports to Secretary of State Cordell Hull and President Roosevelt, published in his book Mission to Moscow which served as the basis of his 1943 Hollywood film, a great contribution to Soviet propaganda efforts as it came from an authoritative eyewitness who was present at these trials in the critical years in and after 1936, and up to 1938. Mission to Moscow was translated into several languages after World War Two, particularly in Eastern Europe, as it did excellent political service to the Soviet Union and to Joseph Stalin personally. Amb. Davies continued his career as a diplomat throughout and right after World War II.

Keywords: Soviet-American relations, Joseph E. Davies, U.S. Embassy in Moscow, Soviet showtrials, Mar-a-Lago, Marjorie Merriweather Post, Mission to Moscow (book and film), Cordell Hull, Franklin Delano Roosevelt

Tibor Frank - Professor Emeritus of History, Eötvös Loránd University, Budapest, Hungary; full member of the Hungarian Academy of Sciences, H-1088 Budapest, Rákóczi út 5.

E-mail: tzsbe@hu.inter.net; Personal website: https://franktibor.hu/;

Wikipedia page: https://en.wikipedia.org/wiki/Tibor_Frank

ORCID: https://orcid.org/0000-0002-9407-972X

1 In: Frank Tibor (szerk.): Az orosz birodalom születései. Magyar kutatók tanulmányai az orosz történelemröl. [The Births of the Russian Empire: Studies on Russian History by Hungarian Researchers.] Budapest: Gondolat, 2016, 255-278. (Расширенный вариант).

DOI: 10.38210/RUSTUDH.2020.2.4 
Несмотря на то, что Соединенные Штаты лишь в 1933 г. установили дипломатические отношения с СССР, они стремились помочь Советской России уже и после 1917 г. С помощью значительных благотворительных мер Америка пыталась смягчить последствия голода, разразившегося в 1921 г. Будущий президент Герберт Гувер (1874-1964), который уже во время Первой мировой войны обратил на себя внимание своими акциями экономической помощи в Европе (главным образом в Бельгии), на основании полученных от Конгресса полномочий при посредничестве Красного креста передал для России из медицинских запасов американской армии товаров на сумму 4 миллиона долларов. Американская государственная помощь имела скорее символическое значение, поскольку в то же время в Россию была направлена помощь на сумму 80 миллионов долларов из частных источников. В 1922 г. благодаря необыкновенным организационным способностям Гувера, ранее работавшего горным инженером, 10,5 миллионов нуждающихся русских людей в 18 тысяч распределительных пунктов получили продовольствие, одежду и лекарства (900 000 тонн). Живший в то время в эмиграции Максим Горький (1868-1936) вдохновенными словами выразил Гуверу благодарность за «великодушие американского народа», которое «воскресило мечту о братстве между народами в то время, когда человечество так остро нуждается в благотворительности и сострадании». На одном из банкетов в Москве председатель Совета Народных Комиссаров РСФСР поблагодарил Гувера «от имени миллионов спасенных людей». ${ }^{2}$

\section{I. РАННИЕ СОВЕТСКО-АМЕРИКАНСКИЕ ДИПЛОМАТИЧЕСКИЕ СВЯЗИ}

В 20-х гг. стороны не желали вести переговоры об установлении дипломатических отношений по двум причинам. Советский Союз не соглашался уплатить государственный долг, возникший в царское время, а кроме этого, согласно американским обвинениям, вел в Центральной Америке политику, нарушавшую интересы США, так, например, через Мексику снабжал оружием никарагуанское

2 DANIEL J. Boorstin, The Americans. The Democratic Experience (New York: Random House/ Vintage Books, 1974), 573. 
революционное движение Аугусто Сесара Сандино (1896-1934). Однако тем временем американские предприниматели утвердились в Советском Союзе - Арманд Хаммер развивал асбестовую и графитовую промышленность, фирма «General Electric» создала электростанцию на Днепре, а Генри Форд построил автомобильный завод в Новгороде. ${ }^{3}$

Соединенные Штаты признали Советский Союз только спустя 16 лет после большевистской революции. Решение об установлении дипломатических отношений приняло правительство Франклина Делано Рузвельта (1882-1945) в ноябре 1933 г. В то время за это решение выступали такие авторитетные американские бизнесмены, как, например, владелец автомобильных заводов Генри Форд (1863-1947) и президент «General Electric Company» Джеральд Своуп (1872-1957), которых манил огромный советский рынок, но этому шагу было радо и советское правительство, надеявшееся на сдерживание японской экспансии. К тому времени и американская сторона уже в течение нескольких лет уповала на антияпонское выступление СССР, в Госдепартаменте его старался подготовить эксперт по дальневосточным делам Стэнли Кул Хорнбек (1883-1966). ${ }^{4}$ В 1938 г. Хорнбек выступал за введение экономических санкций против Японии. ${ }^{5}$ Подготовку установления дипломатических отношений Рузвельт поручил не профессиональному дипломату, а своему тогдашнему другу и доверенному лицу, Уильяму К. Буллиту (1891-1967), который в октябре 1933 г. предложил советскому правительству пригласить в Вашингтон высокопоставленного советского представителя для ведения переговоров. 8-16 ноября 1933 г. советский нарком по иностранным делам Максим Литвинов (1876-1951) провел переговоры с Рузвельтом, который прежде всего попросил разрешить свободное вероотправление американцам, находившимся в СССР. Помимо этого, Литвинов пообещал, что СССР возвратит военный долг в объеме 70-150 миллионов долларов. Формально этот дипломатический шаг

3 MAgYARICS TAMÁs, Az Egyesült Államok külpolitikájának története. Mítosz és valóság: érdekek és értékek (Budapest: Antall József Tudásközpont, 2014), 271.

4 Robert D. Schulzinger, U.S. Diplomacy Since 1900 (New York - Oxford: Oxford University Press, 1998), 156.

5 "Stanley K. Horbeck Urges Economic Sanctions Against Japan, 1938”, in U.S. Department of State: Foreign Relations of the United States, 1938. Washington, D.C., 1954, Government Printing Office, III, 572-573. Другая публикация: DENNIS MERRILL and THOMAS G. PATTERSON (eds), Major Problems in American Foreign Relations. Vol. II. Since 1914 (Boston - New York: Houghton Mifflin, 2000), 121-122. 
мог считаться успешным, однако в течение следующих пяти лет он не принес запланированных и ожидаемых результатов. СССР не дал живущим в стране американцам права на свободное вероотправление и не возвратил военный долг, американские коммерсанты не смогли проникнуть в советскую экономику, а США не оправдали советских ожиданий относительно противодействия японским экспансионистским планам. К концу 1934 г. отношения между двумя державами ${ }^{6}$ снова характеризовались взаимным недоверием.

Первым послом США в СССР стал Уильям К. Буллит, располагавший командой сотрудников, состоявшей из отличных экспертов по советским делам. За два года первоначальное восторженное отношение Буллита к советскому строю сменилось резким антикоммунизмом, и в 1936 г. посол был переведен в Париж. Оставшиеся в Москве сотрудники посольства, в том числе Чарльз Ю. Болен (1904-1974) и Лой У. Хендерсон (1892-1986), во главе с Джорджем Ф. Кеннаном (1904-2005), сыгравшем позже важную роль в развязывании холодной войны, с растущим ужасом следили за «чистками», за уничтожением Сталиным старой большевистской гвардии. Под влиянием антикоммунистически настроенного руководителя восточноевропейского отдела Роберта Ф. Келли (1894-1976) в американском Госдепартаменте в то время началась кампания, имевшая целью обратить внимание политической элиты на коммунистическую опасность. ${ }^{7}$ Этот круг американских дипломатов 1930-х годов и их опыт стали источником сильных антисоветских настроений, проявившихся в период возникновения холодной войны. ${ }^{8}$ В современной американской исторической науке указано на то, что в 40-х гг. Джордж Ф. Кеннан описывал советский коммунистический режим в понятийном контексте социального пола, - советский народ изображен у него в качестве женщины, изнасилованной правительством, а сам Кеннан показан как человек, по-настоящему влюбленный в русский народ. ${ }^{9}$ Работавшие в Москве американские дипломаты единодушно считали, что нет оснований для сотрудничества

6 Robert D. SChUlzInger, U.S. Diplomacy Since, 157; ALAN BRINKLEY, The Unfinished Nation. A Concise History of the American People (New York: McGraw Hill, 2010), 657-658; MAGYARICS TAMÁs, Az Egyesült Államok külpolitikájának története, 271-272.

7 ROBERT D. SCHULZINGER, U.S. Diplomacy Since, 157-158. URL: https://en.wikipedia.org/wiki/ George_F._Kennan [дата обращения: 9 июля 2016 г.].

8 Frank Costigliola, „George F. Kennan and the Gendering of Soviet Russia”, in Major Problems in American Foreign Relations eds. DENNIS MERRILL, THOMAS G. PATERSON, 255.

9 Там же. 
с СССР, и в 30-х гг. казалось, что совместно с Советским Союзом нельзя даже выступать против общих врагов. Сталинские постановочные судебные процессы, ликвидация противников диктатора обусловили антисоветскую настроенность этих дипломатов, сохранявшуюся в течение всей их дальнейшей деятельности.

\section{II. АДВОКАТ В КАЧЕСТВЕ ПОСЛА}

Преемником посла Буллита в Москве стал Джозеф Эдвард Дэвис (1876-1956). Его официальные полномочия длились с 16 ноября 1936 г. до 11 июня 1938 г. Дэвис родился в городе Уотертаун штата Висконсин, учился на юриста в Висконсинском университете $(1898,1901)$, а позже получил степень доктора в Пресвитерианском колледже штата Южная Каролина (1937). Поначалу он работал юристом, затем подключился к политической деятельности Демократической партии. В 1912 г. ему удалось заручиться поддержкой западных американских штатов, благодаря чему он внес эффективный вклад в избрание Вудро Вильсона (1856-1924) президентом США. Став близким сотрудником президента, он был назначен президентом Bureau of Corporations (Бюро корпораций), занимавшегося расследованием экономических злоупотреблений и сращивания интересов в экономике, а также осуществлением контроля за деятельностью трестов, а затем президентом Federal Trade Commission (Федеральной торговой комиссии) (1915-1916), ${ }^{10}$ больше того, по просьбе президента США, он баллотировался в сенаторы (1918). Однако на выборах победил его соперник, кандидат от республиканцев, после чего демократы потеряли большинство в Сенате. Это послужило одной из причин падения президента Вильсона после войны. На Парижской мирной конференции (1919) Дэвис был экономическим советником Вильсона, а после окончания мирных переговоров вернулся к адвокатской практике и работал юридическим консультантом ряда зарубежных государств (Мексики, Перу, Голландии, Греции и Доминиканской Республики). Его самым известным делом была защита акционеров компании «Ford» против иска американского правительства, которая закончилась выигрышем дела и принесла

10 Elizabeth Kimball Maclean, "Joseph E. Davies: The Wisconsin Idea and the Origins of the Federal Trade Commission", Journal of the Gilded Age and Progressive Era 6/3 (2007), 248284. DOI: $10.1017 /$ S1537781400002097 
адвокату рекордный гонорар в 2 миллиона долларов. Дэвис выполнял адвокатскую работу прежде всего по антимонопольным делам, среди его клиентов были «Seagrams», «National Dairy», «Copley Publishing», «Anglo-Swiss», «Nestle» и «Fox Films»."1

Ставший миллионером Дэвис щедро поддерживал из собственных средств предвыборную кампанию Франклина Д. Рузвельта в 1932 г. Он был близким другом и сотрудником Рузвельта еще при администрации Вильсона.12 Выбор президента Рузвельта пал на Дэвиса с учетом его обширного юридического и международного опыта, а также в знак признательности за его неизменную поддержку Демократической партии. Так он получил назначение в Москву. После Москвы, в 1938-1939 гг. Дэвис представлял США в Люксембурге и Бельгии, а в 1939-1941 гг. стал специальным советником госсекретаря Корделла Халла (1871-1955), позже удостоенного Нобелевской премии мира, которому помогал в определении американской внешней политики в начале мировой войны. В 1942 г. Дэвис был назначен председателем созданного по указанию президента Рузвельта «Контрольного совета» по оказанию помощи союзникам во время войны («War Relief Control Board»). В 1945 г. на Потсдамской конференции Дэвис работал в ранге посла специальным советником президента Гарри С. Трумэна (1884-1972) и госсекретаря Джеймса Ф. Бирнса (1882-1972).

В качестве интересной детали личной жизни Дэвиса отметим, что его второй женой (в 1935-1955 гг., то есть и в годы работы в Москве) была Марджори Мерривезер Пост (1887-1973), являвшаяся в свое время самой богатой (и, быть может, самой привлекательной) наследницей в США, владелицей зерновой компании «Postum» и основательницей компании «General Foods». Часть своего свободного времени супруги Дэвис проводили в получившей известность летней резиденции Марджори Пост, особняке Мар-а-Лаго, находившемся в городе ПалмБич во Флориде. Состоявший в то время из 126 комнат особняк позже, в 1985 г., был приобретен мультимиллиардером Дональдом Трампом.

11 Для краткого описания биографии Дэвиса я использовал 3-й том Who Was Who in America (Chicago, IL: Marquis - Who's Who, 1960, 210), а также статью о нем из Википедии. URL: https://en.wikipedia.org/wiki/Joseph_E._Davies [дата обращения: 5 июня 2016 г.].

12 Elizabeth Kimball Maclean, "Joseph E. Davies and Soviet-American Relations, 1941-43", Diplomatic History 4/1, 1980, 73. DOI: 10.1111/j.1467-7709.1980.tb00336.x 


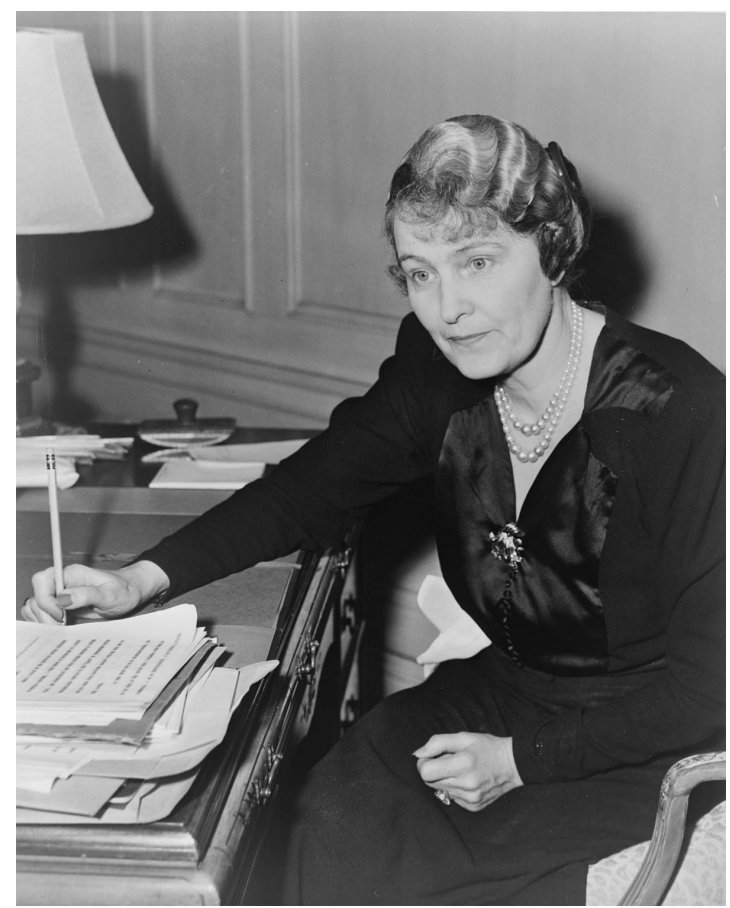

Марджори Мерривезер Пост

\section{III. Миссия в Москву}

Уже в 1841 г. посол Дэвис выпустил книгу о своей деятельности в Москве под названием «Mission to Moscow» [«Миссия в Москву»], которая в свое время стала настоящим международным бестселлером. Она была напечатана в нескольких сотнях тысяч экземпляров, переведена на множество языков, по ней был снят фильм в Голливуде. ${ }^{13}$ Венгерский перевод книги Дэвиса, «Moszkvai jelentés», появился в двух изданиях объемом около 500 страниц сразу после Второй мировой войны в переводе Вильмоша Юхаса (Budapest: Anonymus, 1945). В 1984

13 Joseph E. Davies, Mission to Moscow (New York: Simon and Schuster, 1941; Sydney and London: Angus and Robertson, 1942; London: Victor Gollancz, 1942, 10th impr. 1945). URL: https://archive.org/details/missiontomoscow035156mbp [дата обращения: 1 сентября 2016 г.]. 
профессор Оксфордского университета Ласло Шоймар коротко сравнил венгерский текст с английским оригиналом и указал на то, что венгерский текст во многих местах сильно отличается от оригинала, причем изменения и пропуски всегда делались в соответствии со сталинистской политикой СССР. ${ }^{14}$ Таким образом, в 1945 г. венгерский текст был подвергнут обстоятельной цензуре в соответствии с советскими интересами.

Во время и после войны книга американского дипломата служила прекрасной советской пропагандой. В 1943 г. «Warner Brothers» сняла по этой книге фильм, режиссером которого был Майкл Кёртиц, а в главных ролях снимались Уолтер Хьюстон (Дэвис) и Энн Хардинг (Пост). Этот фильм был частью усилий Голливуда по поддержке союза с СССР в военное время. Дэвис сохранил и пользовался всеми правами, связанными со сценарием, в фильме отразились его ошибочные суждения. Под влиянием книги в фильме нарисован такой пристрастно просталинский образ СССР, что даже продюсер фильма, Роберт Бюкнер назвал его «преднамеренной, политически мотивированной ложью», «явным искажением важных фактов посредством их полностью или частично сознательно неверного показа». ${ }^{15}$ Жертвы московских постановочных процессов представлены в фильме в качестве пятой колонны нацистской Германии. ${ }^{16}$ Ныне московской миссии Дэвиса посвящается все более серьезная научная литература, в первую очередь здесь нужно отметить книги Дэвида Х. Кулберта (1980) и Элизабет Кимбалл Мэклин (1993), а также статью Тодда Беннета. ${ }^{17}$

14 После моего оксфордского доклада по данной теме, сделанного 20 января 2017 г., Ласло Шоймар устно и, по моей просьбе, письменно обратил мое внимание на явно преднамеренные искажения в венгерском переводе и на свою ранее написанную статью об этом: L. R. SOMLAY (= SOlYMÁR LÁSzló), „SUbmission to Moscow (in Hungarian)”, Survey 28/4, 1984, 188-192. В то же время в международной научной литературе (в том числе в книге более позднего американского посла в СССР Чарльза Ю. Болена) уже гораздо раньше было высказано совпадающее с моим, резко осуждающее мнение о Дэвисе и его непонятном благожелательном отношении к Сталину. См., например: DAVID MAYERS, George Kennan and the Dilemmas of US Foreign Policy (New York-Oxford: Oxford University Press, 1988), 43-44, 91.; здесь цитируется CHARLES E. BOHLEN (1904-1974): Witness to History, 1929-1969 (New York: Norton, 1973), 44, 56.

15 David H. CUlbert, Mission to Moscow (Madison, WI: University of Wisconsin Press, 1980), 16-17; Todd BennetT, „Culture, Power, and Mission to Moscow: Film and Soviet-American Relations during World War II", The Journal of American History 88/2, 2001, 489-518. DOI: $10.2307 / 2675103$

16 https://en.wikipedia.org/wiki/Mission_to_Moscow [дата обращения: 7 мая 2016 г.].

17 Culbert, Mission to Moscow; Elizabeth Kimball MaClean, Joseph E. Davies. Envoy To The Soviets (Westport, CT: Praeger Publishers, 1993); TOdD BENNETT, „Culture, Power, and Mission to Moscow". 
Книга Дэвиса ${ }^{18}$ является документом, сотканным из дневника посла и его официальных донесений. В ней содержится множество интересных наблюдений о советской политической, общественной и экономической жизни 1936-1938гг., об известных деятелях и повседневности Советского Союза, о международном положении и советской внешней политике. В книге опубликовано конфиденциальное донесение от 12 марта 1937 г., адресованное госсекретарю Корделлу Халлу, о поездке по СССР, в ходе которой Дэвис осмотрел важнейшие центры советской экономики, посетил множество заводов и крупных предприятий. Большое впечатление произвел на него Донбасс, где «находятся крупнейшие сталелитейные заводы, заводы по производству тяжелых машин и турбин, алюминиевые и тракторные заводы, химические предприятия, заводы сельскохозяйственного машиностроения и другие крупные промышленные предприятия". Его особенно удивило, что «строительство этих промышленных объектов, обучение рабочих и запуск производства были осуществлены за 6-7 лет», хотя «на некоторых таких предприятиях работает около 38 000 мужчин и женщин». 26 февраля 1937 г. Дэвис в сопровождении дочери, секретаря, двух подчиненных ему дипломатов и четырех американских журналистов отправился в шестидневную поездку в Харьков (ныне - Ха́рків). Наряду с множеством промышленных объектов они посетили «первый «Дворец юных пионеров"», где 27 000 школьников «вне обязательных школьных занятий занимаются в научных, художественных, авиационных, транспортных и иных кружках ручного творчества [...] $]^{20}$ Подобные учреждения принадлежат к числу интереснейших достижений СССР и имеются во всех крупных центрах в соответствии с мыслью Сталина о том, что дети являются наиболее ценным достоянием страны». 2128 июля 1937 г. Дэвис подготовил для госсекретаря Корделла Халла подробное донесение об опасениях и слухах, связанных с состоянием советской промышленности. Он утверждал, что огромные пространства СССР и особенно богатство его земель сделали возможным осуществление коммунистического

18 В дальнейшем в качестве оригинала я ссылаюсь на первое австралийское издание книги Дэвиса (Sydney and London: Angus and Robertson, 1942). См. еще доступное в Интернете издание 1945 г.: https://archive.org/details/missiontomoscow035156mbp [дата обращения: 1 сентября 2016 г.].

19 DAVIES, Mission to Moscow, 75.

20 DAVIES, Mission to Moscow, 75.

21 Davies, Mission to Moscow, 75. 
и социалистического эксперимента и позволили достичь заметных результатов.

Это дает возможность не только перенести недостатки и ошибки в области промышленности, но и отказаться от всего вклада промышленности без того, чтобы это потрясло экономику и финансы государства. Пока армия находится в руках партии, последняя может пренебречь вытекающими из этого социальными последствиями.

По всей видимости, это подтверждает конечный вывод, что кризис организации русской экономики и промышленности не столь тяжел, как это обычно думают. Помимо этого вероятно, что если даже мрачные прогнозы о крахе промышленности и экономики осуществятся, то и полный развал промышленности не окажет столь судьбоносного влияния на организм СССР, как это предполагается, поскольку это будет иметь относительно маловажное значение по сравнению с громадными природными богатствами и мощью государственной жизни. ${ }^{22}$

10 июля 1937 г. Дэвис выразил заместителю госсекретаря Самнеру Уеллесу (1892-1961) свое непрекрытое восхищение Советским Союзом: «У этой страны имеются безгранично большие человеческие ресурсы. В этом народе кроется изумительная сила следования идеологическим установкам и преданности делу. K этому еще надо добавить неизмеримые богатства страны. Она уже продемонстрировала много замечательного». ${ }^{23}$ Однако посол ясно оценил и то, что «часть тяжелой промышленности все же жизненно важна и даже может оказать влияние на прочность положения правительства, поскольку необходима с точки зрения военной готовности. [...] Насколько я знаю, ответственные члены правительства очень «сознательно» относятся к возможности войны и считаются с угрозой со стороны Германии и Японии». ${ }^{24}$ Посол сослался на беседу с «президентом» Михаилом Ивановичем Калининым (1875-1946), сказавшим, что „они полностью полагаются на свою армию и чувствуют себя защищенными от всяких нападаений,

22 Davies, Mission to Moscow, 161.

23 Davies, Mission to Moscow, 151.

24 Davies, Mission to Moscow, 161. 
даже если нападения последуют одновременно с двух сторон». В этом отношении Дэвис оказался хорошим наблюдателем, почти пророком, когда добавил, что: «географическое размещение промышленности по стране доказывает, что промышленный план отчасти должен восприниматься как подготовка к войне. [...] По всей видимости, советская промышленность будет хорошо функционировать, если ей придется показать свою настоящую мощь».25

Эти мысли американский посол как бы продолжал в письме сенатору Милларду Тидингсу (1890-1961) от 14 апреля 1938 г., в котором он удивительно верно осуждал изоляцию СССР в Европе.

В этом безумном мире, - писал Дэвис. - дела идут так, что легко может случиться, что мировые демократии будут счастливы, если в случае нового всемирного кризиса здешнее правительство бросит в их интересах на чашу весов свою дружбу, силу и мирные намерения. Поверьте мне, что если фашистские диктаторы будут и дальше ломиться сквозь кусты и колючки, кризис неизбежно окажется у порога. [...] Политики в Европе гоняются за призрачными иллюзиями и ведут страусовую политику по отношению к простым, элементарным силам, которых они не желают принять во внимание. ${ }^{26}$

\section{IV. СТАЛИн}

Американский посол скоро заметил симптомы культа Сталина и уведомил о них Госдепартамент. Он подробно сообщил госсекретарю о трехдневных празднествах по случаю 20-й годовщины Октябрьской революции, проходивших 6-7-8 ноября 1937 г. Ему бросились в глаза огромные гипсовые скульптуры и освещенные портреты Сталина, восторженные овации при упоминании имени Сталина, и он отметил: «Многие родители сажают своих детей на плечи, чтобы и малыши на мгновение увидели Сталина». ${ }^{27}$ И все же в 1938 г. посол Дэвис считал, что «в истории о Сталине, по-видимому, будет отмечено, что он был

25 DAVIES, Mission to Moscow, 161-162.

26 Davies, Mission to Moscow, 249.

27 DAVIES, Mission to Moscow, 176-183, цитата: 182. 
великим строителем России, достойным преемником Петра Великого». В качестве объяснения он добавил: «Лишь за последние двенадцать месяцев в Москве было построено 157 школ». ${ }^{28}$ Уже с самого начала работы в Москве Дэвис буквально восхищался Сталиным и, таким образом, сам стал одним из служителей его культа:

Отовсюду я слышу, что Сталин очень простой человек, пуританин, его самая характерная черта - сила воли, направленная на достижение одной цели, и уникальная работоспособность. Он твердо держит в руках ситуацию в стране. Сталин порядочный человек, живет безупречной жизнью и предан задаче строительства социалистического государства и, в конечном итоге, коммунизма. Он обладает достаточной гибкостью, характеризующей его как политика и крупного вождя. ${ }^{29}$

5 июня 1938 г., перед переездом на место нового назначения, в Брюссель, посол нанес в Кремле прощальный визит главе советского государства Калинину и премьер-министру Вячеславу Михайловичу Молотову (1890-1986). Калинин выразил американскому послу признательность советского руководства за то, что тот «лично изучал на территории СССР различные отрасли промышленности и предприятия, а также различные явления жизни советского народа. Он, как и другие члены правительства, ценит этот объективный подход и, несмотря на то, что между ними и американским послом имеется не одно противоречие, они считают его „порядочным человеком” [...] и поэтому сожалеют о том, что он покидает Москву». ${ }^{30}$ После этого посла Дэвиса проводили к главе правительства Молотову, у которого состоялась его личная встреча со Сталиным. Молотов также принял американского посла в своей квартире. К огромному удивлению дипломата, сразу после его прибытия «в комнату в одиночестве вошел господин Сталин, поспешил ко мне и сердечно приветствовал меня. Затем я в течение двух часов пятнадцати минут беседовал с ним и с Молотовым. [...]

28 DAVIES, Mission to Moscow, 233.

29 DAVIES, Mission to Moscow, 51-52.

30 DAvies, Mission to Moscow, 265. 


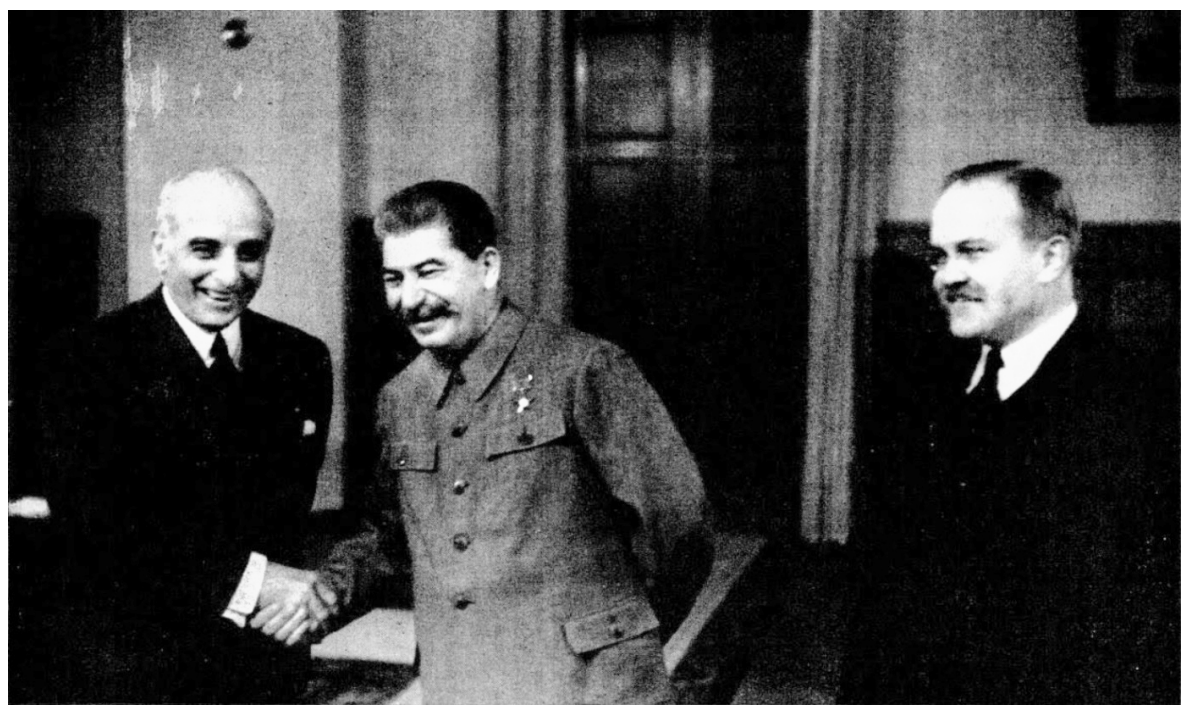

Посол Дэвис со Сталиным и Молотовым

Сталин особенно интересовался президентом Рузвельтом и задавал мне различные вопросы, касавшиеся личности президента. [...] В московском дипкорпусе этот случай, можно сказать, произвел впечатление сенсации. Его считают замечательным исключением в здешней истории дипломатических отношений». ${ }^{31}$ В написанном в тот же день меморандуме посол очень подробно описал состоявшуюся встречу. По его мнению, советский руководитель «вел себя дружелюбно и непосредственно, у него простые манеры, во всем его облике чувствуется внутренняя сила и большая собранность. [...] он сердечно, со скромным достоинством приветствовал меня». ${ }^{32}$ Посол с почтением отзывается о советском партийном лидере, приписывая лично ему все те «необычайные достижения, которые были спланированы и осуществлены за короткие десять лет» и которые «вызвали его восхищение». Дэвис сказал Сталину, что, как он слышал, «Сталин войдет в историю как более крупный строитель государства, чем Петр Великий и Екатерина Великая. [...] Для меня большая честь лично встретиться с человеком, созидательная деятельность которого служит благу простых

31 DAVIES, Mission to Moscow, 262-263.

32 DAvies, Mission to Moscow, 266. 
людей», ${ }^{33}$ - добавил Дэвис. Ответ Сталина не заставил себя ждать: «Он засмущался, сказав, что это не его заслуга. Эта идея зародилась у Ленина. План принадлежал Ленину, ему же первоначально принадлежал и план Днепровской гидроэлектростанции. Не он, Сталин, подготовил и десятилетний план, это был замысел более трех тысяч замечательных специалистов, великий план был создан благодаря им и другим его сотрудникам. Заслуга принадлежит прежде всего советскому народу, сам Сталин отклоняет любые восхваления, адресованные лично ему». Дэвис убежденно присовокупил к словам советского вождя и свое мнение: «Как я видел, его скромность искренна». ${ }^{34}$

Сталин удержал посла и задал ему несколько вопросов. Тогда и выяснилось, почему Сталину была важна личная беседа с послом, к которой он явно основательно подготовился. Ему хотелось обсудить с послом два вопроса, жизненно важных прежде всего с точки зрения совершенствования советских вооруженных сил и являвшихся болевой точкой в советско-американских отношениях. Прежде всего Сталина интересовало, почему задерживается строительство заказанного в Америке для советского флота линкора, дальнейшие копии которого планировалось построить в СССР. Дэвис дал компетентный ответ: «Выполнение работ для заграничных заказчиков разрешается лишь в том случае, если, по мнению командования армии и флота, это не наносит ущерба сухопутной и морской обороне страны».35 Дэвис постарался выяснить, кто вел переговоры о строительстве линкора от имени советского правительства. Из ответа Сталина стало ясно, что это была компания «Сагр», одним из владельцев которой являлся американский мультимиллионер русского происхождения Сэм Карп, шурин Молотова, который, как подозревалось, находился под советским влиянием. ${ }^{36}$ Это дело тянулось уже в течение долгого времени,

33 Davies, Mission to Moscow, 266.

34 DAVIES, Mission to Moscow, 266.

35 Davies, Mission to Moscow, 267.

36 ELLEN MCCLAY, In The Presence of Our Enemies (Bloomington, IN: AuthorHouse, 2006), 67. Женой Молотова была Перл Карповская, в подпольной работе получившая имя Полины Семеновны Жемчужины (1897-1970). Согласно редакционной статье газеты «Milwaukee Sentinel» от 1 декабря 1953 г. (р. 12), Карп до конца 30-х гг. ежегодно посещал СССР, откуда систематически привозил пачки 1000 долларовых банкнот. Одиозная комиссия Конгресса США по расследованию антиамериканской деятельности дважды вызывала Карпа, но так и не добилась от него точных ответов о сумме и судьбе этих денег. В статье говорилось, что Карп был настолько влиятельным человеком, что мог затребовать посла СССР из Вашингтона к себе в Нью-Йорк, больше того, ему 
поскольку руководящие чиновники военно-морского министерства США активно выступали против строительства в США военных кораблей для СССР. Поскольку это министерство было важнейшим заказчиком всех тех предприятий, к которым обращалась компания «Сагр», они имели основания опасаться за свои будущие заказы в том случае, если бы пренебрегли предупреждениями со стороны военно-морского министерства. ${ }^{37}$ Дэвис осторожно заметил Сталину, что президент Рузвельт, по всей видимости, не знает об этом деле, и что сам Дэвис хотел удостоверится в том, что представляющая СССР компания «имеет достаточно авторитетные полномочия для переговоров и пользуется доверием как Сталина, так и советского правительства». ${ }^{38}$

Затем Сталин перешел ко второму вопросу, который касался погашения т. н. «долга Керенского» Соединенным Штатам. ${ }^{39}$ Во время Первой мировой войны уже царское правительство через «First National City Bank» взяло у США заем размером примерно в 86 миллионов долларов, к чему добавились военные облигации на сумму в 11 миллионов долларв, размещенные на американском рынке. После признания правительства Керенского Соединенные Штаты предоставили ему кредит размером в 100 миллионов долларов, который позже был увеличен до 325 миллионов. Российское правительство использовало 187 миллионов из этой суммы. Таким образом, США имели огромные финансовые требования к советскому правительству. К ним можно добавить и частные американские инвестиции, осуществленные до революции, размер которых оценивался в 60594 миллиона долларов. ${ }^{40}$

удавалось дозваниваться до Сталина в Москве. Упомянутый позже Дэвисом Дэвид А. Розофф, будучи руководителем советского торгового предприятия «Амторг», работал под руководством Карпа. См.:

https: / news.google.com/newspapers?nid=1368\&dat=19531130\&id=A44XAAAAIBAJ\&sjid=X RAEAAAAIBAJ\&pg=4284,3925861\&hl=en [дата обращения: 22 июля 2016 г.].

37 ThOMAS R. MADDUX, «Relations in the 1930s. The Soviet Union's Efforts to Purchase Naval Vessels», in Donald J. Stoker JR. - Jonathan A. GRAnt (eds): Girding for Battle. The Arms Trade in a Global Perspective, 1815-1940 (Westport, CT - London: Praeger, 2003), 206.

38 DAVIES, Mission to Moscow, 268.

39 Александр Федорович Керенский (1881-1970) - российский адвокат, депутат Государственной думы, в 1917 г. министр и в течение короткого времени премьерминистр. В 1918 г. был вынужден эмигрировать, умер в эмиграции.

40 "The Roosevelt Administration and the Russian Problem», in Soviet-American Political and Trade Relations. CQ Researcher, http://library.cqpress.com/cqresearcher/document. php?id=cqresrre1933022400 [дата обращения: 4 июня 2016 г.]. Эти данные совпадают с данными П. В. Оля: Р. V. ОнL, Foreign Capital in Russia (Petrograd, 1922). 
Посол Дэвис изложил историю предложений, касающихся погашения русского/советского долга, начиная с 1933 г. Советское правительство, особенно после признания СССР (16 ноября 1933 г.) Соединенными Штатами, хотело получить у США заем. Однако после принятия Конгрессом законопроекта сенатора Хайрама Джонсона (1866-1945) закон Johnson Debt Default Act (1934) запретил предоставлять американские займы странам, которые не урегулировали свои прежние задолженности. Этот закон не имел преимущественно антисоветской направленности, став следствием международного финансового кризиса, последовавшего за Великой депрессией. ${ }^{41} \mathrm{~B}$ результате американское правительство не удовлетворило советскую просьбу о новом займе. Поскольку на этой ранней стадии советскоамериканских переговоров уже ожидалось принятие законопроекта Джонсона, нарком по иностранным делам Литвинов и новый президент США в меморандуме 1933 г. декларировали, что новый заем может быть предоставлен не правительством Соединенных Штатов, а американскими частными лицами. Согласно полученным инструкциям, Дэвис не должен был обострять это крайне запутанное и становившееся все более безнадежным дело, но слова Сталина подействовали на посла успокоительно: «Советское правительство разыскивает способы для хотя бы частичного погашения задолженности».42 Смысл этого туманного ответа состоял в том, что СССР был бы не в состоянии погасить сразу все свои международные долги (в том числе задолженность Англии и Франции), поэтому он брался выплатить только долг американскому государству. В беседе со Сталиным Дэвис последовательно подчеркивал, что хочет лишь ознакомиться с деталями советского предложения, поскольку не имеет полномочий делать какие-либо заявления по этому вопросу и не знает, «на что согласится и на что не согласится его правительство».43

После разговора со Сталиным Дэвис немедленно приступил к основательному изучению вопроса о советских долгах. Через несколько дней, 8 и 9 июня, он посетил Молотова, который сделал письменное предложение, касавшееся советских планов урегулирования

41 https://en.citizendium.org/wiki/Johnson_Debt_Default_Act_of_1934 [дата обращения: 16 июня 2016 г.]. О его предыстории см. замечательную книгу моей бывшей американской студентки: KATHERINE A. S. SIEgEL, Loans and Legitimacy. The Evolution of Soviet-American Relations, 1919-1933 (Lexington, KY: The University Press of Kentucky, 1996), 138.

42 DAVIES, Mission to Moscow, 270.

43 Davies, Mission to Moscow, 271. 
задолженности. Молотов выразил признательность «президенту и госсекретарю» за благоприятную оценку и хорошее мнение. «Он сказал, что удастся ли это дело или нет, но они во всяком случае засвидетельствовали их благие намерения». ${ }^{4}$ Пресса не получила информации об этих переговорах.

17 января 1939 г., уже будучи послом в Бельгии, Дэвис еще раз вернулся к предыстории предложения Молотова. В обобщающем донесении, направленном госсекретарю, он сообщил, что летом 1938 г. президент и госсекретарь уполномочили его сделать советскому правительству более благоприятное предложение по вопросу о долге Керенского. Согласно этому плану, американское правительство должно было предоставить СССР компенсационные займы в случае погашения им долга Керенского в узком смысле этого понятия (то есть не всех русских и советских долгов). Однако для этого требовалось, чтобы Сенат США предоставил такую же возможность и Венгрии, которая также была обременена долгами, связанными с Первой мировой войной. По этому вопросу венгерское правительство 8 февраля, а затем повторно 16 августа 1937 г., направило США предложение, которое уже 28 марта было передано президентом Конгрессу.

В предложении венгерского правительства предусматривалось погашение процентов по американскому займу в течение трех лет (то есть с 15 декабря 1937 г. до 15 июня 1940 г.) полугодичными взносами по почти 10000 долларов каждый. Таким образом, в этом случае речь шла всего о годовой 1 процентной ставке венгерского долга общим размером около 2 миллионов долларов, отчасти относившегося ко времени до начала Первой мировой войны, но венгерское предложение все же имело международное значение. Дело в том, что Венгрия была к тому времени единственной страной, которая старалась реструктурировать свою задолженность США и принять меры по выплате процентов. В венгерском предложении признавалась задолженность по основному долгу и предусматривалось ее погашение в течение 25-30 лет взносами по 40000 долларов. ${ }^{45}$

44 Davies, Mission to Moscow, 273.

45 Госсекретарь Корделл Халл президенту Ф. Д. Рузвельту, Вашингтон, 25 августа 1937 г.; Меморандум зам. советника по международной экономике [Фредерика] Ливси, Вашингтон, 9 декабря 1937 г.; Меморандум советника по международной экономике Г[ерберта] Ф[ейса], Вашингтон, 21 декабря 1937 г., 850-855. Опубликовано в: Foreign Relations of the United States. Diplomatic Papers 1937 (том 1-5), Vol. 1: General (Washington: United States Government Printing Office, 1954). 
Дальнейшая судьба венгерского предложения выходит за пределы выбранной нами темы и требует дальнейших архивных изысканий. Однако с венгерской точки зрения заслуживает особого внимания уже то, что Джозеф Э. Дэвис информировал советское правительство и поблагодарил его за дружественную готовность в деле погашения русских/советских долгов в свете и в соответствии с содержанием шагов, связанных с венгерским государственным долгом. ${ }^{46}$

\section{V. МОСКОВСКИЕ ПРОЦЕССЫ}

Чем больше мы занимаемся взглядами посла Дэвиса на экономику, общество и международную роль СССР, на значение и роль Сталина, тем сильнее удивляемся его политической слепоте и глухоте при наблюдении за постановочными процессами, развернувшимися как раз во время его пребывания в Москве. А ведь во многих случаях он не просто получал информацию об этих процессах, но и лично наблюдал за их ходом в качестве приглашенного на них дипломата. Непосредственные сотрудники посла, в том числе Джордж Ф. Кеннан, критиковали эту политическую беспечность, однако и Кеннан не смог повлиять на свего начальника, который даже инициировал отзыв Кеннана из Москвы. ${ }^{47}$ Из некоторых замечаний Дэвиса становится ясно, что в дипломатическом корпусе в Москве шли оживленные споры о процессах. В одной из своих «дневных заметок» Дэвис рассказал об ужине у дуайена дипкорпуса, афганского посла, где тоже вспыхнул такой спор. Дэвис внимательно выслушал аргументы афганского дипломата, по мнению которого,

русский уголовный кодекс, который основан на «Кодексе Наполеона», не обеспечивает обвиняемому той защиты, которая обычно обеспечивается и русским частным правом. [...] По его мнению, нет более важного источника человеческого достоинства и личной свободы, чем та

46 Посол в Бельгии Джозеф Э. Дэвис госсекретарю Корделлу Халлу, Брюссель, 17 января 1939 г., 594-595. Опубликовано в: Foreign Relations of the United States. Diplomatic Papers. The Soviet Union 1933-1939. Washington: United States Government Printing Office, 1952). Смотри еще: Department of Press Releases, 2 апреля 1938 г., 423.

47 WiLSOn D. MisCAMBlE, "George Kennan. A Life in the Foreign Service”, Foreign Service Journal 81/2, 2004, 23. 


\begin{abstract}
защита от произвола сильных, которую предоставляют человеку законы страны. Он считает, что степень цивилизованности можно измерять в соответствии с тем, какую защиту обеспечивает государство лицу, обвиняемому в совершении преступления даже в том случае, если преступление совершено против самого государства. Он высказал свои замечания о праве отказа обвиняемого от дачи показаний против самого себя и о необходимости того, чтобы суд предполагал и считал возможным его невиновность. ${ }^{48}$
\end{abstract}

Дэвис добавил к этому: «Чистая, ясная искренность этого мудрого и тонко чувствующего человека произвела на меня глубокое впечатление».

Это влияние совершенно не чувствуется при чтении книги Дэвиса. А между тем он с особым вниманием следил за процессами. Прямо в начале книги он приводит свою сделанную сразу после вручения вверительных грамот дневниковую запись о процессе Радека ${ }^{49}$, «за ходом которого я следил с величайшим интересом». ${ }^{50}$ Американский посол следил и за голосами, предупреждавшими об истинной природе процессов. Из слов некоего не названного по имени посла, записанных в дневник 30 января 1937 г., Дэвису могло стать ясно, что в московских дипломатических кругах считают, что процесс «является постановочной комедией, выражением внутренней борьбы между большевиками. Он утверждает, что признания были получены с помощью угроз и полицейских методов физического принуждения». ${ }^{51}$ Зато первого февраля Дэвис беседовал о процессе с литовским послом, который считал очевидным наличие широкого заговора. 52

Здесь будет уместно вспомнить то, о чем напоминал в своем московском дневнике Эрвин Шинко: «...слышался ли хотя бы один голос, который свидетельствовал бы о минимальном нравственном

48 DAVIES, Mission to Moscow, 53.

49 Карл Бернгардович Радек (1885-1939) - советский политический деятель, сторонник Троцкого, от которого позже отрекся. В августе 1936 г. был арестован, его дело слушалось в январе 1937 г. в рамках т. н. «процесса семнадцати» (где в числе обвиняемых, помимо Радека, были Пятаков, Сокольников, Серебряков). Он был приговорен к десяти годам тюрьмы, в 1939 г. был убит в тюрьме.

50 DaVIES, Mission to Moscow, 36.

51 DAVIES, Mission to Moscow, 39.

52 Davies, Mission to Moscow, 52. 
мужестве обвиняемых или тех лиц, которые публично комментировали этот процесс? И была ли у меня какая-то, пусть самая маленькая причина [...] считать свое поведение во время процесса РадекаПятакова ${ }^{53}$ гораздо более правильным, чем поведение всех остальных? Есть ли у меня какая-то, пусть самая маленькая моральная причина для самодовольства, могу ли я считать себя исключением, не был ли я поражен такой же, всеобщей, недостойной человека деморализованностью, которая так или иначе поразила всех, кто жил тогда в СССР? [...] я сделал то же, что и все остальные, - не сделал ничего». ${ }^{54}$

В начале апреля, во время своего пребывания в Вашингтоне, Дэвис убедился в том, что процесс Радека сильно занимал и президента Рузвельта. В отчете посла, сделанном на обеде в Белом доме, президента «больше всего заинтересовал процесс, он задал много вопросов, касающихся его подробностей. Прежде всего его внимание привлекло обвинение в изменнических связях обвиняемых с Германией и Японией. Он хотел услышать мои впечатления о судьях, прокурорах и уголовном судопроизводстве». ${ }^{55}$

Посол постоянно следил и комментировал акции, связанные со сталинскими «чистками», но практически никогда не высказывал своих сомнений или каких-либо существенных политических комментариев. ${ }^{56}$ Его доверчивость, наивность становится особенно заметной летом 1937 г., во время казней генералов Красной армии. Он посветил этому целую главу под названием «Почему расстреляли Тухачевского?».57 В ней он писал: «я старался взвесить факты и увидеть, что скрывается за разнообразием мнений и соображений живущих здесь людей. [...] Моя цель состояла в том, чтобы узнать общее мнение о случившемся; особенно в отношении того, какова в настоящее время сила правительства и каковы его дальнейшие перспективы». ${ }^{58}$ Снова выразив уверенность в том, что после «чисток»

53 Георгий Леонидович Пятаков (1890-1937) - украинский анархист, террорист, советский политический деятель, жертва сталинских процессов.

54 SInKó ERvin, Egy regény regénye. Moszkvai naplójegyzetek 1935-1937 (Budapest-Újvidék: Magvetö-Forum, 1988), 537.

55 DaVIES, Mission to Moscow, 107.

56 Davies, Mission to Moscow, 119-156, 199-215.

57 Davies, Mission to Moscow, 145-149. Михаил Николаевич Тухачевский (1893-1937) - маршал Советского Союза, заместитель председателя Реввоенсовета СССР, заместитель наркома обороны. Стал жертвой сталинской «чистки». 
советский режим стал сильнее, чем когда-либо раньше, ${ }^{59}$ и приведя «общее убеждение» дипломатического корпуса, «что обвиняемые действительно совершили преступления, которые в СССР караются смертной казнью», ${ }^{60}$ Дэвис сообщил и о том, что «не удалось отыскать фактических доказательств, которые действительно пролили бы свет на случившееся, прежде всего на дело командиров Красной армии, и сомнительно, что это станет возможно в обозримом будущем». ${ }^{61}$ В то же время, желая успокоить адресата этого пространного донесения, госсекретаря, Дэвис в примечании добавил, что «шесть месяцев спустя в материалах процесса Бухарина ${ }^{62}$ увидели свет и доказательства по этому делу. Несомненно, что военный суд уже тогда был в целом знаком с этими фактами». ${ }^{63}$ Поразительно, что при этом Дэвис посчитал важным именно тогда (!) похвалить, более того, возвеличить Сталина, который, по его мнению, «заслуживает большого уважения. Он порядочный, скромный, сдержанный, целеустремленный человек, прямодушно мыслящий и действующий мужчина, посвящающий все свои силы коммунизму и возвышению пролетариата. (...) Во всяком случае нужно сказать, что Сталин и внутри партии является самой выдающейся личностью, человеком, которого называют „приятным боссом", то есть начальником, который дает своим сотрудникам возможность для самостоятельных решений». ${ }^{64}$

Самая потрясающая глава написана послом США о процессе Бухарина и называется «Чистка поражает Бухарина». В этой, пятой части его книги, помимо донесений госсекретарю, содержатся выдержки из дневника и писем, а также особенно зловещий отрывок, помеченный 1941 годом и вставленный «по причине логической связи» с процессом, поскольку в этом отрывке говорится о том, «как процессы

59 DAVIES, Mission to Moscow, 148.

60 DAVIES, Mission to Moscow, 154.

61 DaVIES, Mission to Moscow, 153.

62 Николай Иванович Бухарин (1888-1938) - советский идеолог и политический деятель, председатель Коминтерна, главный редактор газеты «Известия». Стал жертвой сталенской «чистки».

63 Davies, Mission to Moscow, 154.

64 DAVIES, Mission to Moscow, 147. Мнение американского посла о Сталине можно легко сравнить с действительностью на основании огромной специальной литературы о Сталине. Из работ на венгерском языке я хотел бы выделить следующие: BÉLÁDI LÁSzló - KRAUSz TAMÁs, Sztálin (Budapest: Láng Kiadó, 1988); ISAAC DEUTSCHER, Sztálin (Budapest: Európa, 1990); Edvard RAdzInSzKIJ, Sztálin (Budapest: Európa, 1997); SImon Sebag Montefiore, Sztálin - A Vörös Cár udvara (Budapest: Alexandra, 2009). 
об измене родины уничтожили „пятую колонну” Гитлера в России». ${ }^{65}$ Дэвис, который 4-12 марта 1938 г. «каждый день» ${ }^{66}$ присутствовал на слушаниях «Большого процесса» по делу Бухарина и его партийных товарищей, сам признался, что «мне было очень трудно без дрожи смотреть на скамью подсудимых. Там сидел заместитель наркома Крестинский, которому я годом раньше передал свои верительные грамоты; нарком по делам торговли Розенгольц, который в этом же месяце прошлого года принимал меня в гостях в своем загородном доме; доктор Плетнев, специалист по сердечным болезням, который оказывал мне врачебную помощь, и которого я очень хорошо знал, был среди них также и нарком финансов Гринько. Все они сидели на скамье подсудимых чуть ли не в трех метрах от меня». ${ }^{67} 8$ марта посол выслушал показания доктора Левина против «руководителя тайной полиции Ягоды», который «хотел вынудить его и его друзей „залечить до смерти" Максима Горького и его сына, и среди целей заговорщиков была и дискредитация Кремля». «Страшная и странная история», - прибавил к этому Дэвис. ${ }^{68}$ Объяснением всему этому служило то, что Ягода якобы «смертельно влюбился в красивую жену молодого Горького и рассердился на Горького старшего за то, что тот вмешивался и мешал „треугольнику"». 69

Дэвис выказывал свою доверчивость и не характерную для адвоката наивность не только в сообщениях начальству. В письме от 8 марта 1938 г., адресованном знакомой с ситуацией в Москве дочери, Эмлен Грожан, он прямо заявил о своей вере в то, что «в ходе судебного разбирательства [...] выявятся [...] контуры заговора; они хотели свергнуть нынешнее правительство, и это им почти удалось. [...] Оченьочень интересные показания Бухарина, Крестинского и других [...] создают впечатление, что опасения [...] Кремля были обоснованными. Теперь выяснилось, что в начале ноября 1936 г. был составлен заговор с целью осуществления государственного переворота в мае следующего года. Во главе заговора стоял Тухачевский. [...] Правительство [...] действовало с максимальной энергией и быстротой. Генералы Красной армии были расстреляны, всю парторганизацию вычистили, вымели железной метлой. Затем выяснилось, что атмосфера заговора заразила

65 Davies, Mission to Moscow, 209-215, цитата: 209.

66 DAVIES, Mission to Moscow, 206.

67 DAVIES, Mission to Moscow, 205.

68 DAVIES, Mission to Moscow, 206.

69 DAVIES, Mission to Moscow, 206. 
и нескольких ведущих руководителей, которые действительно сотрудничали с секретными службами Германии и Японии». ${ }^{70}$ В своем дневнике Дэвис удивительно связал свои впечатления от «Большого процесса» с проблемой русского/советского долга.

Я снова побывал на судебном заседании. «Последние слова» Плетнева, Розенгольца и других были душераздирающе интересными и трагичными. Едва прошел год с того времени, когда мы были приглашены на обед на даче Розенгольца в обществе Гринько, Крестинского, государственного прокурора Вышинского, судьи Ульриха, Микояна, Розова и Ворошилова. ${ }^{11}$ На некоторых из них не произвело никакого впечатления, когда я сказал, что опасность внешней войны могла бы побудить их уплатить нам их долги. Та часть гостей, которая ныне находится на скамье подсудимых, по собственному признанию, прямо желала войны! Иначе считал Ворошилов, а также несколько его соратников. Тогда - год назад - он выступал за погашение долгов Соединенным Штатам.22

Через несколько дней после объявления приговора, последовавшего ранним утром 13 марта, посол доносил госсекретарю Корделлу Халлу, что

на основании каждодневного наблюдения за свидетелями и их показаниями и непроизвольными признаниями, а также на основании других фактов, касающихся процесса, [...] я пришел к убеждению, что перечисленные в обвинительном акте преступления, нарушающие советские законы, были подтверждены достаточным количеством доказательств для того, чтобы, по трезвому размышлению, мы могли считать справедливым приговор, вынесенный обвиняемым за измену родине, а также

70 DAVIES, Mission to Moscow, 207-208.

71 Дмитрий Дмитриевич Плетнев (1872-1941), Аркадий Павлович Розенгольц (1889-1938), Григорий Федорович Гринько (1890-1938), Николай Иванович Крестинский (1883-1938), Андрей Януарьевич Вышинский (1883-1954), Василий Васильевич Ульрих (1889-1951), АЕенастас Иванович Микоян (1895-1978), Климент Ефремович Ворошилов (1881-1969), Давид Аронович Розов (1902-1941).

DAvies, Mission to Moscow, 208. 
наказание, назначенное в соответствии с Уголовным кодексом СССР. Дипломаты, систематически посещавшие судебные заседания, пришли к однозначному убеждению, что на процессе было разоблачено наличие сильной политической оппозиции и серьезного заговора $[. . .]^{73}$

В 1941 г., через несколько дней после того, как нацистская Германия напала на Советский Союз, Джозеф Э. Дэвис сделал доклад в клубе своей альма-матер, Чикагского университета, и ответил на вопросы слушателей. Один из них поинтересовался тем, «„как обстоит дело с пятой колонной в России?” я без колебаний ответил: „Ее там нет. Их всех расстреляли"».7 В этой дневниковой по характеру записи Дэвис мысленно вернулся на место и ко времмени своей миссии в Москве и написал:

Теперь я снова, с этой точки зрения перечитал сообщения о судебных заседаниях и сделанные тогда собственные записи. Я пришел к выводу, что на этих процессах выступившие с признанием советские квислинги и показания свидетелей разоблачили и обнародовали буквально все приемы и интриги немецкой пятой колонны, как они нам известны теперь. ${ }^{75}$

73 Davies, Mission to Moscow, 209. О московских постановочных процессах имеется обширная и много раз порождавшая дискуссии научная литература. Помимо биографий Сталина, опубликованных и на венгерском языке, выделяются следующие paботы: ROBERT CONQUEST, The Great Terror. A Reassessment (Oxford - New York, Oxford University Press, 1968, 40 th Anniversary Ed. 2008); ROBERT TUCKER, Stalin in Power. The Revolution from Above, 1928-1941 (New York: Norton, 1992); VADIM Z. RogOVIN, 1937. Stalin's Year of Terror (Oak Park, MI: Mehring Books, 1998); JÖRG BABEROWSKI, Der rote Terror. Die Geschichte des Stalinismus (München: DVA, 2003); KARL SCHLÖGEL, Terror und Traum. Moskau 1937 (München: Hanser, 2008); Vadim Z. Rogovin, Stalin's Terror of 1937-38. Political Genocide in the USSR (Oak Park, MI: Mehring Books, 2009); JÖRG BABEROWSKI, Verbrannte Erde. Stalins Herrschaft der Gewalt (München: C. H. Beck, 2012) DOI: 10.17104/9783406709623; StePhen Kotkin, Stalin. Volume I: Paradoxes of Power, 1878-1928 (London: Penguin Press, 2014); Douglas O. LINDER, The Moscow Purge Trials (1936-38). Selected Links \& Bibliography. http:// law2.umkc.edu/faculty/projects/ftrials/moscowpurge/moscowlinks.html [дата обращения: 28 июля 2016 г.].

74 Davies, Mission to Moscow, 210.

75 DAVIES, Mission to Moscow, 210-211. 
Нападение нацистской Германии заставило Дэвиса радикально переосмыслить московские процессы. В записи, помеченной 1941 годом, он поведал о том, что во время процессов ни он, ни работавшие тогда в Москве американские журналисты не интересовались потенциальными немецкими и японскими аспектами этих процессов. Их внимание было приковано к «драматической схватке» между Сталиным и Троцким, «о происках пятой колонны мы даже не думали [...]». ${ }^{76}$ Однако после нападения Германии против СССР Дэвису, так сказать, стало ясно, что «история, обнаружившася на этих процессах, действительно разоблачила существование, деятельность и подпольную работу пятой колонны, действовавшей в СССР.. Дэвис повторил известные обвинения, прозвучавшие на советских постановочных процессах, и для подтверждения своих собственных «прозрений» привел на основании судебных протоколов цитаты их показаний обвиняемых. «Теперь стало ясно, что все эти процессы, чистки и ликвидации, казавшиеся в свое время такими жестокими и шокировавшие весь мир, были частью энергичных и напряженных усилий правительства Сталина, стремившегося защититься не только от внутренней революции, но и от нападения извне. Оно проделало основательную работу, и страна была очищена от всех предателей, от „второго фронта". Последовавшие затем события освободили правительство от всех подозрений». ${ }^{78}$ Эти слова служат важными доказательствами того, что Дэвис не просто неверно оценил советские постановочные процессы и сталинские «чистки», но попытался тенденциозно интерпретировать и объяснить их в соответствии с актуальными нуждами советских властей. Мы вступили бы на зыбкую почву, пытаясь обнаружить за этим какую-то подрывную деятельность советсих органов, подкуп американского посла. Гораздо вероятнее, что Дэвис старался служить политике Франклина Д. Рузвельта и Демократической партии США, делу складывавшейся антигитлеровской коалиции и советско-американского сближения во время Второй мировой войны и отыскать рациональное объяснение непонятному и необъяснимому миру сталинской паранойи. ${ }^{79}$

76 DAVIES, Mission to Moscow, 212.

77 DAVIES, Mission to Moscow, 212.

78 DAVIES, Mission to Moscow, 215.

79 Robert Dallek, Franklin D. Roosevelt and American Foreign Policy, 1932-1945: With a New Afterword (Oxford: Oxford University Press, 1979). 


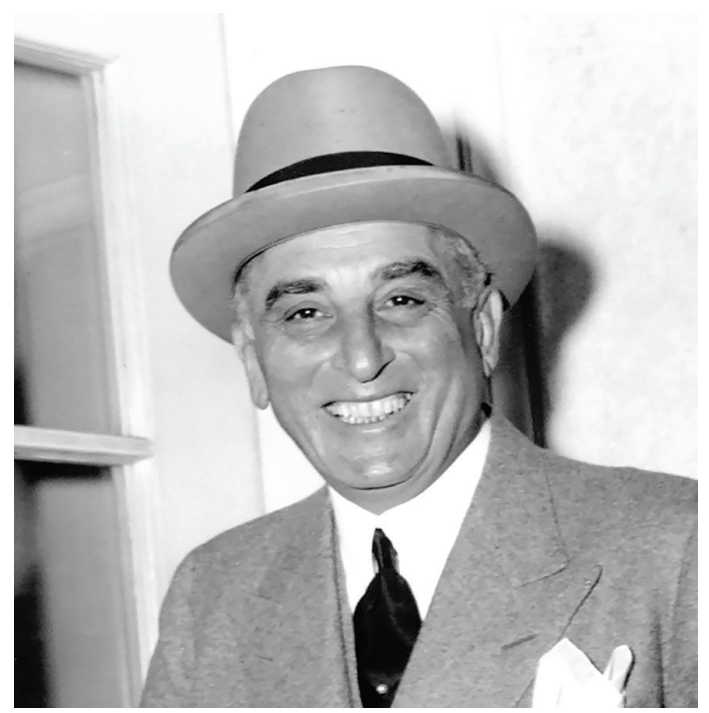

Джозеф Э. Дэвис

\section{CHOBA B MOCKBE}

Во время и после Второй мировой войны Дэвис неизменно пользовался особым доверием Рузвельта и Трумэна и выполнял особо важные поручения, касавшиеся Советского Союза. В мае 1943 г. Дэвис поехал в Москву с новой миссией. На этот раз он отправился в почти месячную поездку, чтобы передать Сталину секретное письмо президента Рузвельта. Поскольку из-за военных действий было бы неосмотрительно ехать через Европу, Дэвису пришлось следовать окольным путем длинной около 26000 миль из Нью-Йорка через Бразилию, Сенегал, Египт, Ирак и Иран в Куйбышев, откуда он через Сталинград прибыл в Москву. На обратном пути он снова достигАмерики проехав через Новосибирск и Аляску. Всего он совершил путешествие протяженностью в 41246 км. ${ }^{80}$ В своем письме Рузвельт предложил Сталину встретиться для личных переговоров, на которых, кроме них, присутствовали бы только переводчик и стенограф. Сталин предложил провести встречу в Фэрбенксе, на Аляске, между 15 июля и 15 августа. Он

80 Журнал «Life», 4 октября 1943 г. 
попросил Дэвиса особо подчеркнуть президенту, что из-за обширных завоеваний Гитлера СССР нужно гораздо больше поставок по лендлизу ${ }^{81}$. Дэвис с удивлением увидел, что в американском посольстве в Москве сохранилась та же атмосфера враждебности и предубеждений, которая существовала и в бытность его послом. Как мы знаем из записи самого Дэвиса, посланец президента Рузвельта постарался объяснить сотрудникам посольства, что публичная американская критика Советского Союза может нанести крупный ущерб военному союзу. ${ }^{82}$

После Второй мировой войны Дэвис снова выполнял важные дипломатические поручения, еще раз оказавшись в центре мировой политики. В мае 1945 г. президент США Трумэн направил его в Лондон для переговоров с премьер-министром Великобритании Черчиллем. ${ }^{83}$ Согласно дневниковой записи Дэвиса, в мае 1945 г. Трумэн сказал ему, что хочет отложить запланированные переговоры со Сталиным и Черчиллем на июль, когда закончатся испытания атомной бомбы. ${ }^{84}$ На Потсдамской конференции глав трех великих держав Дэвис в ранге посла был советником президента Трумэна.

81 Закон о ленд-лизе (11 марта 1941 г.), сделал возможными поставки оружия и военных материалов в СССР и Великобританию.

82 JOSEPH E. DAVIES, Missions for Peace - 1940-1950; неопубликованная рукопись, находящаяся в собственности Библиотеки Конгресса. URL: https://en.wikipedia.org/ wiki/Joseph_E._Davies [дата обращения: 5 июня 2016 г.]. Об этом см. важную работу Elizabeth Kimball Maclean: Joseph E. Davies and Soviet-American Relations, 1941-43, 73-94.

83 Davies Confers With Churchill; Expected to See Eden and Other Officials Today - Topic of Talk Secret. By Clifton Daniel. By Wireless To the New York Times. May 28, 1945. URL: https:// www.nytimes.com/1945/05/28/archives/davies-confers-with-churchill-expectedto-see-eden-and-other.html

84 Дневниковая запись Дэвиса, 21 мая 1945 г. Joseph E. Davies Papers, Library of Congress, Box 17. Опубликовано: WiLliAm BURR (ed.), National Security Archive Electronic Briefing Book, No. 162. URL: https://nsarchive2.gwu.edu/NSAEBB/NSAEBB162/ [дата обращения: 28 июля 2016 г.]. ROBERT D. SCHULzINGER (ed.), A Companion to American Foreign Relations (Oxford: Blackwell Publishing Ltd., 2003). https://onlinelibrary.wiley. com/doi/pdf/10.1002/9780470999042.biblio [дата обращения: 28 июля 2016 г.]. DOI: $10.1002 / 9780470999042$.biblio 
VII. ДЖОЗЕФ Э. ДЭВИС ПОБЫВАЛ И В ВЕНГРИИ

Сначала, в ходе европейской поездки 1937 года, он лично вел переговоры с президентом Чехословакии Эдвардом Бенешем (1884-1948), который затронул и вопросы, связанные с Малой Антантой и Венгрией. Во время их беседы Бенеш отчасти отнес Венгрию к числу «тоталитарных авторитарных» государств, но отметил и то, что чехословацко-венгерские отношения улучшились. Бенеш произвел на Дэвиса сильное впечатление, и он отозвался о чехословацком президенте как об «одном из самых талантливых и блестящих государственных деятелях Европы». ${ }^{85}$

В конце сентября Дэвис посетил и Будапешт, где уже бывал и раньше, и, хотя и не застал посла Монтгомери, все же хорошо провел время, ему нравилась венгерская столица и нравились венгры. ${ }^{86}$ В этот раз Дэвис долго беседовал с правителем Миклошем Хорти (1868-1957). Свои впечатления он обобщил так: «Несмотря на его возраст, он выглядит сильным и уверенным в себе человеком. Он один из тех необычайно сильных и талантливых мужчин, с которыми я встречался в Европе. Он тверд в своих убеждениях, темпераментен и собран». ${ }^{87}$

Дэвис поддерживал добрые, сердечные отношения с американским послом в Венгрии Джоном Ф. Монтгомери (1878-1954), который был его другом. ${ }^{88}$ В июне 1938 г. они вместе плыли по океану из Саутгемптона в Нью-Йорк на борту океанского лайнера «СС Вашингтон». ${ }^{89}$

85 Джозеф Э. Дэвис госсекретарю Корделлу Халлу, Вильфранш, 13 сентября 1937 г. Опубликовано: Foreign Relatons of the United States. Diplomatic Papers 1937, Vol. 1.: General (Washington: United States Government Printing Office, 1954), 124-127.

86 Джозеф Э. Дэвис - Джону Ф. Монтгомери, Будапешт, 27 сентября 1937 г.; Джон Ф. Монтгомери - Джозефу Э. Дэвису, 26 октября 1937 г.; Джозеф Э. Дэвис - Джону Ф. Монтгомери, Москва, 3 ноября 1937 г. John F. Montgomery Papers, Sterling Memorial Library, Yale University, MS Group \#353, Vol. IV.

87 L. NAGY ZSUZSA, „Amerikai diplomaták jelentései Horthy Miklósról”, História 1990, №/5-6, 20.

88 Frank TiBor (szerk.), Roosevelt követe Budapesten (Budapest: Corvina, 2002), 11-12.

89 «Я с радостью предвкушаю приятную встречу с ним». Дневниковая запись Дэвиса от 17 июня 1938 г. In: DAVIES, Mission to Moscow, 286. 


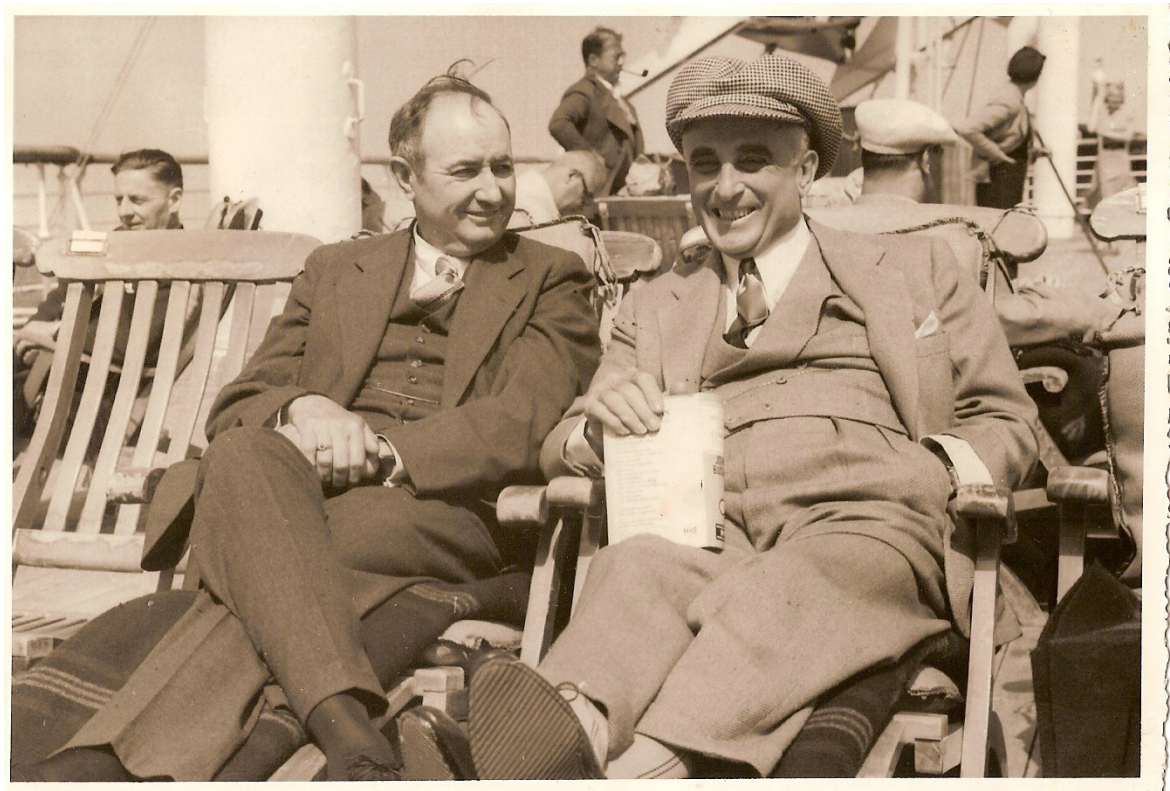

Картина № 4. Джон Ф. Монтгомери и Джозеф Э. Дэвис

В сохранившейся части их переписки, охватывающей отрезок времени с 1937 по 1939 г., речь идет в основном о личных делах Монтгомери и содержится мало политически значимых моментов. Однако и тут появляются ошибочные политические взгляды и прогнозы Дэвиса. 13 февраля 1939 г. он писал своему другу Монтгомери из Брюсселя в Будапешт, что «согласно морю разных толков, достаточно вероятно, что в течение следующих месяцев следует ожидать возникновения специфических кризисов со множеством военных «тревог», однако в здешних дипломатических кругах господствует мнение, что мы переживем этот год без серьезной вспышки враждебности».90

90 Джозеф Э. Дэвис - Джону Ф. Монтгомери, Брюссель, 13 февраля 1939 г. John F. Montgomery Papers, Sterling Memorial Library, Yale University, MS Group \#353, Vol. V. 


\section{VIII. ПО СЛЕДАМ ОДНОЙ ТАЙНЫ}

Дэвис сильно ошибся, и не в первый раз. Крайне удивительно, что столь преуспевающий, располагающий большим опытом американский адвокат и юрисконсультант не понял истинной природы московских процессов. Как могло случиться, что, сидя в первых рядах зала судебных заседаний, он не удивился, смотря на страшно безучастные лица и понурые фигуры, слушая примитивно сфабрикованные показания его бывших личных, хороших друзей, высокопоставленных правительственных чинов и политиков, в один момент превращенных в обвиняемых и подвергнутых унизительным пыткам? Возможно ли, что, несмотря на доверие вышестоящих политиков, этот отличный бюрократ не разбирался в мировой политике, а его ошибки вытекали просто из плохого знания людей, неверной оценки ситуации и американской наивности? Орден Ленина91, полученный им в 1945 г., не доказвает, что ранее он работал на СССР. Могли ли его шантажировать? Не верится. Может быть, он чего-то боялся? Почему, кого и чего? Почему он не верил своим отличным, обладавшим острым умом сотрудникам посольства и коллегам-послам, которые четко понимали ситуацию?

С наибольшей вероятностью ответ содержится в опубликованных биографиях жены посла Джозефа Э. Дэвиса. Дело в том, что Дэвис и госпожа Пост получили от советских властей в подарок или по особо льготным ценам необычайно ценные произведения искусства, присходившие из наследия царской семьи, конфискованные у аристократов, принадлежавшие Третьяковской галерее или находившиеся в собственности жертв сталинского террора. Эти приобретения предназначались для собственных коллекций русского искусства супругов Дэвис.92 По всей вероятности, эти подарки влияли

91 Inventory file of the presentation of the Order of Lenin to Joseph E. Davies on 30 November 1945. URL: http://alliance.rusarchives.ru/inventory-file-presentation-order-lenin-josephe-davies-30-november-1945 [дата обращения: 20 августа 2020 г.].

92 В статье Википедии https://en.wikipedia.org/wiki/Marjorie_Merriweather_Post [дата обращения: 28 апреля 2018 г.] приводится источник этих утверждений: William Wright, Heiress: The Rich Life of Marjorie Merriweather Post (New Republic Books, 1978), CM. об этом еще: NANCY RUBIN STUART, American Empress: The Life and Times of Marjorie Merriweather Post (iUniverse, 2004); ESTELLA M. CHUnG, Living Artfully: At Home with Marjorie Merriweather Post (GILES, 2013); LIANA PAREDES, Spectacular: Gems and Jewelry from the Merriweather Post Collection (Hillwood Estate, Museum \& Gardens, 2017); HowARD VINCENT KURTZ, Ingenue to Icon: 70 Years of Fashion from the Collection of Marjorie Merriweather 
на позицию посла. Более точно мотивы и причины поведения Дэвиса могут быть выяснены только с помощью дальнейших исследований, главным образом работы в московских архивах. ${ }^{93} \mathrm{~K}$ сказанному выше следует добавить, что, по свидетельству биографического послесловия к книге Дэвиса и висконсинской прессы, в 1937 г. посол, родившийся в Висконсине, подарил свою коллекцию русских произведений искусства (точнее, ее часть) Висконсинскому университету, где он когда-то учился. В 1938 г. там был напечатан каталог подаренных предметов. ${ }^{94}$ Часть коллекции посол хранил у себя до самой смерти. После его кончины, в 1976 г., эта часть коллекции была продана на аукционе «Сотбис», а вырученные средства пошли на погашение долгов Вашингтонского кафедрального собора. В этом соборе покоятся останки Дэвиса. ${ }^{95}$ Происхождение и местонахождение всех предметов из коллекции Дэвиса может быть уточнено в ходе дальнейших исследований.

В то же время несомненно, что письменные донесения и устные отчеты Дэвиса, дружественные по отношению к Советскому Союзу и способствовавшие более доброжелательному отношению к Сталину, оказывали влияние на президента Рузвельта и госсекретаря Корделла Халла, помогали создать и сохранять антигитлеровскую советскоамериканскую коалицию. Сильно цензурированный венгерский перевод его книги только усилил изначальные просоветские (и просталинские) интонации Дэвиса. Факт остается фактом - несмотря на свое капитальное заблуждение, он на свой лад и своими средствами внес существенный вклад в победу союзников во Второй мировой войне.

Герб посла Дэвиса, полученный им в 1939 г. от Геральдической палаты Великобритании, ныне используется в качестве фирменного знака компанией «The Trump Organization». За плагиат грозит предъявление президентского иска. ${ }^{96}$

Post (Washington, D.C.: Hillwood Estate, Museum \& Gardens, 2015). Миссис Дэвис тоже получила советские художественные подарки, см.: DAVIES, Mission to Moscow, 271.

93 Журнал «Life», 4 октября 1943 г. Cр.: DAVIES, Mission to Moscow, 499.

94 Davies, Mission to Moscow, 499; The Joseph E. Davies Collection of Russian Paintings and Icons, Presented to the University of Wisconsin:

Catalogue (University of Wisconsin, 1938). https:/ / books.google.hu/ books?id=yvHVAAAAMAAJ\&q=UNIVERSITY+OF+WISCONSIN\&hl=hu\&source=gbs_word_ cloud_r\&cad=5 [дата обращения: 20 августа 2020 г.].

95 Joseph E. Davies. https://en.wikipedia.org/wiki/Joseph_E._Davies [дата обращения: 21 августа 2020 г.].

96 Right to bear arms? Trump accused of plagiarising family crest, BBC, 2017-05-31. 